\title{
A Novel and Highly Sensitive Reduced Graphene Oxide Modified Electrochemical Sensor for the Determination of Chlorpyrifos in Real Sample
}

\author{
Berna Koçak $^{1 *}$, Hüseyin Çelikkan ${ }^{2}$ \\ ${ }^{1}$ Munzur University, Tunceli Vocational School, Chemical and Chemical Processing Technologies Department, \\ Tunceli, Turkey \\ ${ }^{2}$ Gazi University, Faculty of Science, Department of Chemistry, Ankara, Turkey \\ *berna.kocak@hotmail.com 1 , celikkan@gmail.com 1 \\ Received date: 7.09.2020, Accepted date: 28.12 .2020
}

\begin{abstract}
In this study, the voltammetric behavior of chlorpyrifos(CPF) was investigated using reduced graphene oxidemodified glassy carbon electrode(RGO/GCE). FT-IR, XRD and TEM methods were employed in the characterization of graphene oxide and reduced graphene oxide prepared by Hummers' method. Electrochemical characterization of $\mathrm{CPF}$ was determined by cyclic voltammetry $(\mathrm{CV})$ and differential pulse voltammetry(DPV). Determination of CPF was performed by differential pulse adsorptive stripping voltammetry (DPAdSV) on RGO/GCE. Two working ranges between $5.19 \times 10^{-7}-8.12 \times 10^{-6} \mathrm{M}$ and $8.12 \times 10^{-6}-2.18 \times 10^{-3} \mathrm{M}$ were obtained in the CPF calibration curve created by DPAdSV method on RGO/GCE and the limit of detection was found to be $1.56 \times 10^{-7} \mathrm{M}$. Recovery of CPF from tap water samples on RGO/GCE was $101.0 \%$. In conclusion, a selective and sensitive sensor was developed for the determination of $\mathrm{CPF}$, which can be used in real samples.
\end{abstract}

Keywords: Chlorpyrifos, modified electrode, reduced graphene oxide

\section{Klorpirifosun Gerçek Örnekte Tayini İçin Yeni ve Yüksek Hassasiyetli İndirgenmiş Grafen Oksitle Modifiye Edilmiş Elektrokimyasal Sensör}

\section{$\ddot{\mathbf{O} z}$}

$\mathrm{Bu}$ çalışmada, klorpirifosun(CPF) voltametrik davranışı, indirgenmiş grafen oksitle modifiye edilmiş camsı karbon elektrot(RGO/GCE) kullanılarak incelendi. Hummers yöntemiyle hazırlanan grafen oksit ve indirgenmiş grafenoksitin karakterizasyonunda FT-IR, XRD ve TEM yöntemleri kullanıldı. CPF'nin elektrokimyasal karakterizasyonu, dönüşümlü voltametri(CV) ve diferansiyel puls voltametriyle(DPV) ile belirlendi. RGO/GCE'ta CPF'nin tayini diferansiyel puls adsorptif sıyrrma voltametrisiyle(DPAdSV) yapıldı. RGO/GCE'ta CPF'nin DPAdSV yöntemiyle oluşturulan kalibrasyon grafiğinde $5.19 \times 10^{-7}-8.12 \times 10^{-6} \mathrm{M}$ ve $8.12 \times 10^{-6}-2.18 \times 10^{-3} \mathrm{M}$ olmak üzere iki çalışma aralı̆̆ı belirlendi. LOD değeri $1.56 \times 10^{-7} \mathrm{M}$ 'dir. RGO / GCE ile musluk suyu örneklerinde CPF geri kazanımı \% 101,0'dir. Sonuç olarak,CPF tayini için gerçek numunelerde kullanılabilen seçici ve duyarlı bir sensör geliştirilmiştir.

Anahtar kelimeler: Klorpyrifos, modifiye elektrot, indirgenmiş grafen oksit

\section{INTRODUCTION}

Chlorpyrifos(CPF) is a broad-spectrum organophosphate insecticide that is widely used in agriculture, urban life, and household pest control(Pope et al., 2005; Nallapaneni et al., 2005; Sirisha et al., 2007).

This pesticide is applied to cereal crops, cotton, field crops, fruits, hazelnut, vegetables, ornamental plants, and grass. CPF is also effective in controlling worms, cockroaches, fleas, flies, termites and, lice.
$\mathrm{CPF}$ acts on the central nervous system, heart, and respiratory system. Exposure to CPF is linked to acute symptoms such as coordination disorders, dizziness, headache, shivering, cramps, blurred vision, and dyspnea(difficulty in breath). When exposed to higher levels, it leads to loss of consciousness, the paroxysm of laughter, and death(Nallapaneni et al., 2005). The determination of $\mathrm{CPF}$ is, therefore, of vital importance. Methods 
such as HPLC-UV-VIS(Handajani et al., 2017), HPLC-MS/MS(Huan et al., 2019), GC-MS(Sinha et al., 2006), colorimetry (Mane et al., 2020) were developed for the determination of CPF. However, despite the accuracy and high sensitivity of these methods, they come with certain drawbacks including high costs, time-consuming processes such as pre-concentration, and bulky devices that are not suitable for fieldwork. Therefore, a simpler, faster and, cost-efficient method is required to detect CPF(Huang et al., 2020). Electrochemical methods were employed for simple, fast and cost-efficient determination of CPF(Al-Meqbali et al., 1998; Manisankar et al., 2005; Sirisha et al., 2007; Pelit et al., 2011; Kumaravel et al., 2015; Sreedar et al.,2015; Fischer et al. J.,2016; Melo et al.,2018; Joshi et al., 2020)

Being one of the most prominent elements of the periodic table, carbon has a total of five allotropes including fullerene, carbon nanotube, graphene, graphite, and diamond. While diamond and graphite which have been known since ancient times are three-dimensional allotropes, nanotube discovered in the $90 \mathrm{~s}$ is one-dimensional and fullerene is zero-dimensional. On the other hand, the recently-discovered graphene which attracted a great deal of attention after its discovery is twodimensional. The electronic structure of the graphene layers was first discussed by Wallace in 1947(Wallace, 1947). In 2004, Novoselov and Geim mechanically extracted a single-layer of graphene using the exfoliation method and characterized, with various methods, the graphene compressed as a preliminary process of the research for making electrochemical sensors (Novoselov et al., 2004). Graphene is widely used in electrochemical and electroanalytical applications thanks to its relatively low cost, wide specific surface area(theoretically $\left.2630 \mathrm{~m}^{2} / \mathrm{g}\right)($ Manisankar et al., 2008)and higher electron mobility $\left(15000 \mathrm{~cm} \mathrm{~V}^{-1} \mathrm{~s}^{-1}\right)($ Geim et al., 2010; Yang et al., 2010) compared to carbon nanotube and fullerene.

In this study, a new-generation, simple, sensitive, reliable, and easily-preparable electrode modified with reduced graphene oxide(RGO/GCE) was employed in the electrochemical determination of CPF. To obtain the RGO used in GCE modification, GO was first synthesized from graphite using the Hummers method and then was reduced by $\mathrm{NaBH}_{4}$. And lastly, it was characterized using FT-IR, XRD, and TEM methods. Differential pulse adsorptive stripping voltammetry(DPAdSV) was performed and the conditions for the quantitative determination of $\mathrm{CPF}$ on $\mathrm{RGO} / \mathrm{GCE}$ were unveiled.

\section{MATERIAL AND METHODS}

\section{Instrumentation and chemicals}

Iviumpocketstat(potentiostat galvanostat impedance analyzer) was used for voltammetric measurements of CPF and the data collected through this device were evaluated with the Ivium software. Shimadzu IR Affinity-1was used to determine the functional groups of graphene oxide and graphite via FT-IR spectroscopy. Atomic force microscope(Nanosurf Easy scan2, Nanosurf Instruments Inc.) and transmission electron microscope(JEOL TEM 1400) were used respectively for the determination of thickness and size of graphene layers. A three-electrode system was employed during the experimental studies, where glassy carbon electrode(CHI104) served as the working electrode, while $\mathrm{Ag} / \mathrm{AgCI}(3 \mathrm{M} \mathrm{NaCI})$ electrode(MF-2052, BAS) was used as the reference electrode and $\mathrm{Pt}$ wire as the counter electrode.

All the chemicals used in the experimental studies were in analytical purity. Sulfuric $\operatorname{acid}\left(\mathrm{H}_{2} \mathrm{SO}_{4}\right)$ was purchased from Carbo Erba(CAS no:7664-93-9); sodium hydroxide $(\mathrm{NaOH})$ (CAS no: 1310-73-2), sodium nitrate $\left(\mathrm{NaNO}_{3}\right)$ (CAS no : 7631-99-4), sodium chloride ( $\mathrm{NaCl})(\mathrm{CAS}$ no: 764714-5), sodium carbonate $\left(\mathrm{Na}_{2} \mathrm{CO}_{3}\right)$ (CAS Number: 497-19-8), calcium chloride dihydrate $\left(\mathrm{CaCI}_{2} \cdot 2 \mathrm{H}_{2} \mathrm{O}\right)$ (CAS No: 10035-04-8), lead nitrate $\left(\mathrm{Pb}\left(\mathrm{NO}_{3}\right)_{2}\right)$ (CAS No: 10099-74-8), nickel nitrate hexahydrate $\left(\mathrm{Ni}\left(\mathrm{NO}_{3}\right)_{2} \cdot 6 \mathrm{H}_{2} \mathrm{O}\right)$ (CAS No: 13478-007), cobalt nitrate $\left(\mathrm{Co}\left(\mathrm{NO}_{3}\right)_{2}\right)$ (CAS No: 10026-22-9), copper nitrate trihydrate $\left(\mathrm{Cu}\left(\mathrm{NO}_{3}\right)_{2} \cdot 3 \mathrm{H}_{2} \mathrm{O}\right)$ (CAS No: 10031-43-3) from Merck and $\mathrm{CPF}\left(\mathrm{C}_{9} \mathrm{H}_{11} \mathrm{CI}_{3} \mathrm{NO}_{3} \mathrm{PS}\right)$ (CAS no:2921-88-2) from Dr. Ehrenstorfer $\mathrm{GmbH}$. The purity of the argon gas(Ar) used was $99.99 \%$. All of the experiments were conducted in room conditions.

\section{Synthesis of reduced graphene oxide(graphene)}

Chemical synthesis of the reduced graphene oxide(graphene)(RGO) was performed in two steps. The first step included the production of graphene oxide(GO) from graphite, while the second step 
involved producing RGO by reducing the graphene oxide. The synthetic graphite was converted into graphene oxide(GO) using the Hummers method(AlMeqbali et al., 1998). To this end, the graphite was put into a beaker and then placed inside an ice bath. After the addition of concentrated $\mathrm{H}_{2} \mathrm{SO}_{4}$ and $\mathrm{KMnO}_{4}$, it was stirred for 30 minutes while maintaining the temperature below $20{ }^{\circ} \mathrm{C}$. Then, the solution was removed from the ice bath and stirred for a further 30 minutes at room temperature, and then deionized water was slowly and carefully added. Stirring continued for another 30 minutes after the temperature reached $98^{\circ} \mathrm{C}$. After that, pure water $\mathrm{H}_{2} \mathrm{O}_{2}$ was added to the solution, which turned into a yellow-brown color. At this point, nonreactive potassium permanganate and manganese dioxide were reduced to $\mathrm{Mn}^{2+}$ with the addition of $\mathrm{H}_{2} \mathrm{O}_{2}$. Following the completion of the stirring process, the solution was centrifuged. The precipitate was washed 5 times with $5 \% \mathrm{HCl}$ solution. To confirm the completion of the washing process, $\mathrm{BaCl}_{2}$ was added to the washing water. In case the $\mathrm{BaSO}_{4}$ precipitate was observed, the washing process resumed. After the washing process was completed, the solid graphene oxide was dried in a vacuum drying oven at $60^{\circ} \mathrm{C}$.

Step two: the GO solution was obtained at $1 \mathrm{mg}$ $\mathrm{mL}^{-1}$ concentration with deionized water. It was sonicated in the ultrasonic bath for 2 hours to ensure the homogeneous suspension of GO. Then a $1 \mathrm{M}$ $\mathrm{NaOH}$ solution was used to bring the $\mathrm{pH}$ of the GO solution to 10. To reduce graphene oxide, $\mathrm{NaBH}_{4}$ was slowly added to this solution and it was mixed at $80^{\circ} \mathrm{C}$ for 6 hours. The obtained RGO suspension was washed 5 times with distilled water. Finally, the volume of the solution was completed with deionized water to $100 \mathrm{~mL}$. The prepared RGO suspension with $1 \mathrm{mg} \mathrm{mL}^{-1}$ concentration was used to modify the electrode surface. The obtained RGO solution was then dried for 2 days in a vacuum oven at a temperature of $60{ }^{\circ} \mathrm{C}$ for characterization.

\section{Preparation of RGO modified glassy carbon electrode}

The RGO solution that had a concentration of 1 $\mathrm{mg} \mathrm{mL}^{-1}$ in water was kept in an ultrasonic bath until it was dispersed. $5 \mu \mathrm{L}$ was taken from the dispersed RGO solution, dripped on the cleaned and dried surface of the GCE, and left to dry under room conditions. The electrode that dried up during the day was used for electrochemical studies after it was washed with deionized water(Kang et al.,2010).

\section{Voltammetric measurements}

All voltammetric studies of CPF were $\begin{array}{lllllll}\text { conducted in } 10 & \mathrm{ml} & 0.1 & \mathrm{M} & \mathrm{NaOH}\end{array}$ solution(Manisankar et al.,2005). Before the voltammetric analysis, high purity argon (99.99\%) was purged into the electrochemical cell for 5 minutes to remove the oxygen. Conditioning of graphene modified glassy carbon electrode (RGO/GCE) was performed by cyclic voltammograms(25 times) in the potential range of 0 $\mathrm{V}$ to $-2.1 \mathrm{~V}$ at a scan rate of $100 \mathrm{mVs}^{-1}$. CPF was determined by differential pulse adsorptive stripping voltammetry(DPAdSV) on RGO/GCE(pulse amplitude: $80 \mathrm{mV}$, staircase potential: $6 \mathrm{mV}$, scan rate: $50 \mathrm{mV} \mathrm{s}^{-1}$, pulse time: $7 \mathrm{~ms}$, quiet time: $15 \mathrm{~s}$ ).

\section{Preparation of tap water samples of chlorpyrifos}

A stock solution of $1.0 \times 10^{-4} \mathrm{M}$ CPF was prepared by mixing $1 \mathrm{~mL}$ tap water, $1 \mathrm{~mL}$ acetonitrile, and $8 \mathrm{~mL} 0.1 \mathrm{M} \mathrm{NaOH}$ solution.The same solution without CPF was used as a blank solution for further experiments.

\section{RESULTS AND DISCUSSION \\ Characterization of GO and RGO}

FT-IR spectroscopy was applied to determine the functional groups of GO and RGO. Figure 1a depicts the FT-IR spectra of GO and RGO. From Figure 1a, FT-IR spectrum of GO showed the broadband of $\mathrm{O}-\mathrm{H}$ stretching vibrations around 3300 $\mathrm{cm}^{-1}$, the sharp band of $\mathrm{C}=\mathrm{O}$ stretching vibrations at $1717 \mathrm{~cm}^{-1}, \mathrm{C}=\mathrm{C}$ stretching of unoxidized graphitic domain at $1617 \mathrm{~cm}^{-1}$, C-O stretching of carboxylic acid at $1041 \mathrm{~cm}^{-1}$ (William et al., 1958; Paredes et al., 2008; Konios et al.,2014; Çiplak et al., 2015)

From Figure 1a, it can be concluded that after the reduction of graphene oxide, the main difference was the absence of the broad band of $\mathrm{O}-\mathrm{H}$ stretching. The other vibrations of oxygencontaining functional groups at the RGO spectrum were decreased by the reduction process of GO(Koçak et al., 2015).

XRD spectra of GO and RGO were shown in Figure 1b. XRD technique is very useful to confirm the reduction of graphene oxide regarding the decrease of interlayer distance. The characteristic sharp peak of (002) plane of $\mathrm{GO}$ at $2 \mathrm{\Theta}=11.1$ was related to the 
distance of $0.79 \mathrm{~nm}$ between GO layers(Figure 1b). The corresponding broad peak of RGO at $2 \Theta=23.8$ was the(002) plane of RGO with $0.37 \mathrm{~nm}$ of interlayer distance(Figure 1b). This decrease verified that GO was successfully reduced to RGO(Johra et al., 2014; Emiru et al., 2017)

The surface morphologies and flake dimensions of GO and RGO were depicted by TEM images in
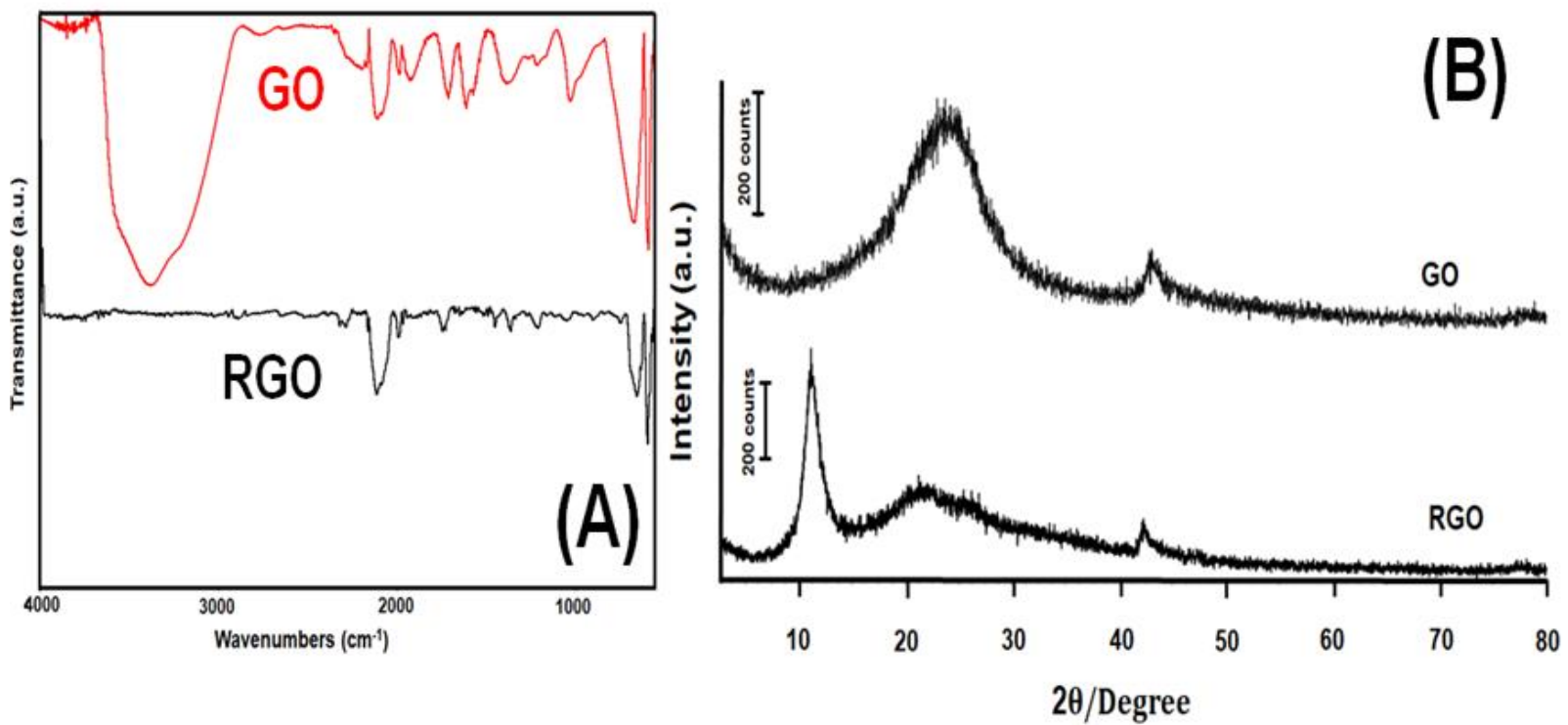

Figure 1. FTIR spectra of $G O$ and $R G O(A), X R D$ images of $G O$ and $R G O(B)$

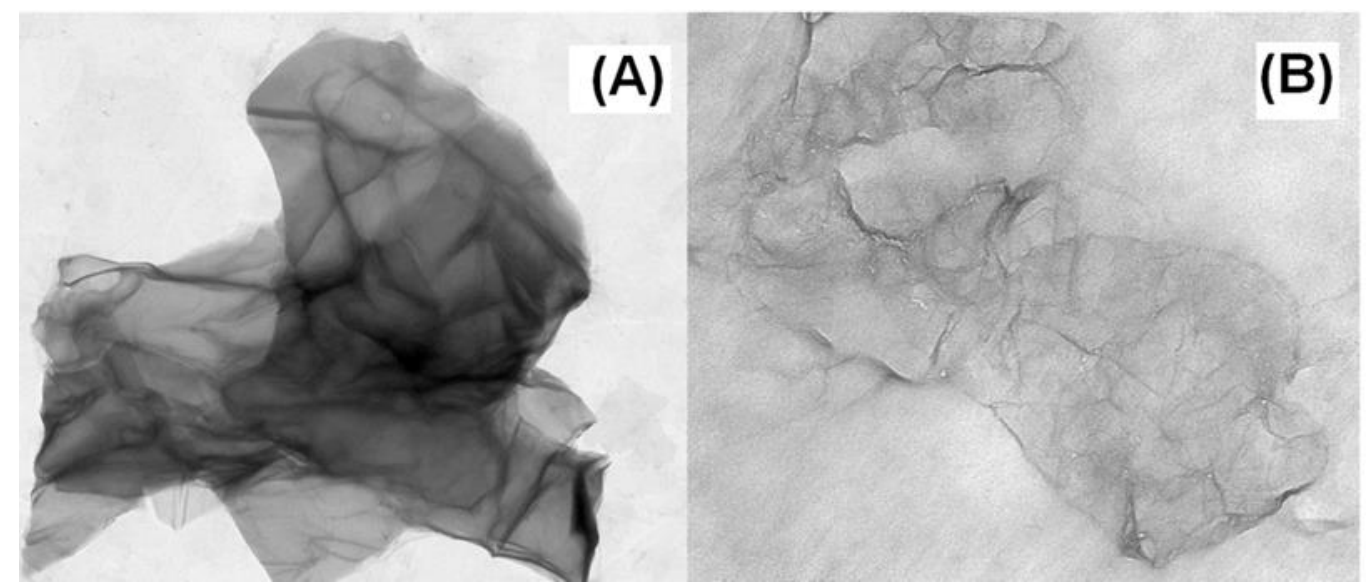

Figure 2. FTIR spectra of GO and RGO (A), XRD images of GO and RGO (B)

Figure $2 \mathrm{a}$ and Figure $2 \mathrm{~b}$, respectively. GO sheets were typically wrinkled and consisted of few layers $(n<5)$ due to stacking. In Figure 2b, RGO sheets were less wrinkled and folded than the oxidized form.

\section{Electrochemical behavior of CPF.}

$\mathrm{CV}$ analyses of CPF were performed on RGO/GCE and $\mathrm{GCE}$ in $0.1 \mathrm{M} \mathrm{NaOH}$. CV of $\mathrm{CPF}$ were scanned from $0 \mathrm{~V}$ to $-2.1 \mathrm{~V}$ in negative direction and from $2.1 \mathrm{~V}$ to $0 \mathrm{~V}$ in positive direction.

In the CVs of $4.98 \times 10^{-5} \mathrm{M}$ CPF in $0.1 \mathrm{M} \mathrm{NaOH}$ taken at GCE, the first peak was $-1.620 \mathrm{~V}(1.27 \mu \mathrm{A})$, the second peak was $-1.749 \mathrm{~V}(1.25 \mu \mathrm{A})$ and the third 
peak was $-1892(1,31 \mu \mathrm{A})$, while at $\mathrm{RGO} / \mathrm{GCE}$, the first peak was $-1.623 \mathrm{~V}(0.78 \mu \mathrm{A})$, the second peak was $-1.754 \mathrm{~V}(1.09 \mu \mathrm{A})$ and the peak peak was $1.903 \mathrm{~V}(0.84 \mu \mathrm{A})$ (Figure 3).

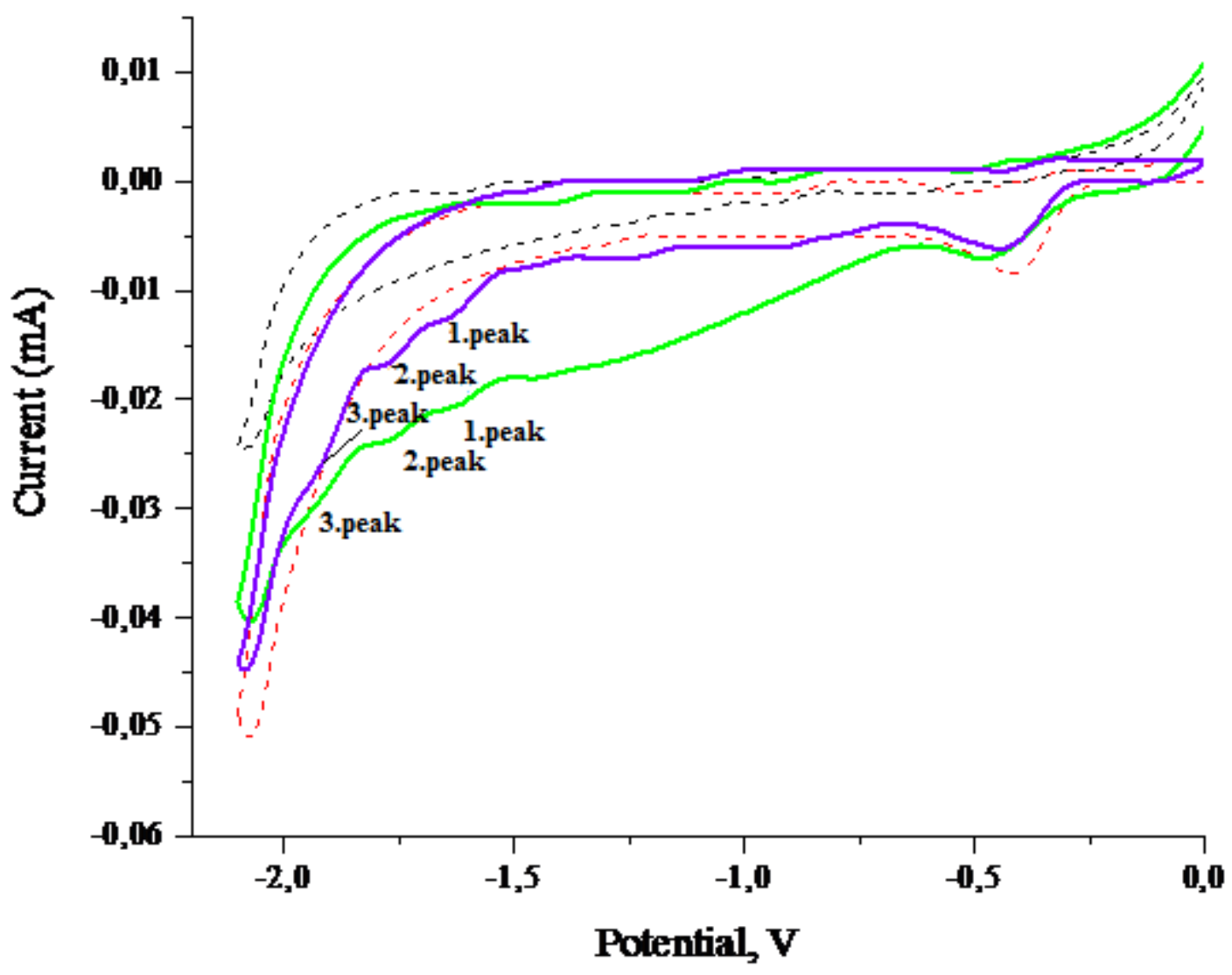

Figure 3.CVs of 4.98x $10^{-5} \mathrm{M}$ CPF peak currents at GCE (purple line) and RGO/GCE (green line) in $0.1 \mathrm{M}$ $\mathrm{NaOH}$ solution; $5 \mathrm{ml} 0.1 \mathrm{M} \mathrm{NaOH}$ solution at GCE(black line) and RGO/GCE(red line) (scan rate:50 $\mathrm{mV} \mathrm{s}^{-1}$ )

The reason for the peak of $\mathrm{CPF}$ at a potential close to the hydrogen evolution area is the electro negativity of chlorine atoms in the molecule. From the literature, the electron density of $\mathrm{C}=\mathrm{N}$ was decreased by the chlorine atoms, which caused the observation at a more negative potential of electrochemical reduction of CPF (Stobinski et al., 2014; Kumaravel et al., 2015).

The diagnosis of adsorbed CPF was explored by the effect of scan rate on the voltammetric response, which should give a linear response for the case of $\operatorname{logip}-\log v$ with 1 of slope value(Manisankar et al., 2005).The voltammograms showing current responses at different scan rates and the plots of logip-logv for CPF at RGO/GCE were presented in Figure $4 \mathrm{a}$ and Figure $4 \mathrm{~b}$, respectively. From Figure $4 \mathrm{a}$, three reduction peaks were observed in the cathodic scan(negative direction), but no peak was present in the reverse scan. It was clearly understood that CPF was irreversibly reduced and electron transfer occurred in 3 separate reduction steps. The first reduction peak was the reduction of the $\mathrm{C}=\mathrm{N}$ structure of pyridine and the second peak was the reduction which occurred with the result of $2 \mathrm{e}^{-}$of the intermediate product.In the study they carried out in 1998, El-Shawi and Kamal examined the electrochemical behavior of CPF in the buffer solutions of $\mathrm{pH}=3, \mathrm{pH}=5, \mathrm{pH}=7.5$, and $\mathrm{pH} \geq 9.5$. In 
this study, the peak was divided into two consecutive small peaks in the strong alkaline environment of CPF $\mathrm{PH} \geq 9.5$. They argued that this behavior was due to the emergence of two consecutive single-electron reduction stages of trichloropyridol, a degradation product of CPF, or the reduction of two different oriented types. In our study, the appearance of three peaks can be attributed to the electrochemical reduction of chlorpyrifos and trichloropyridol, the degradation product, in a strong basic environment.

Although the literature reports that these peaks are diffusion-controlled(Stobinski et al., 2014; Kumaravel et al., 2015), RGO/GCE showed the adsorption effect of CPF and its intermediate products onto the electrode surface from the plot of $\operatorname{logip}-\log \mathrm{v}$ in Figure 4b).

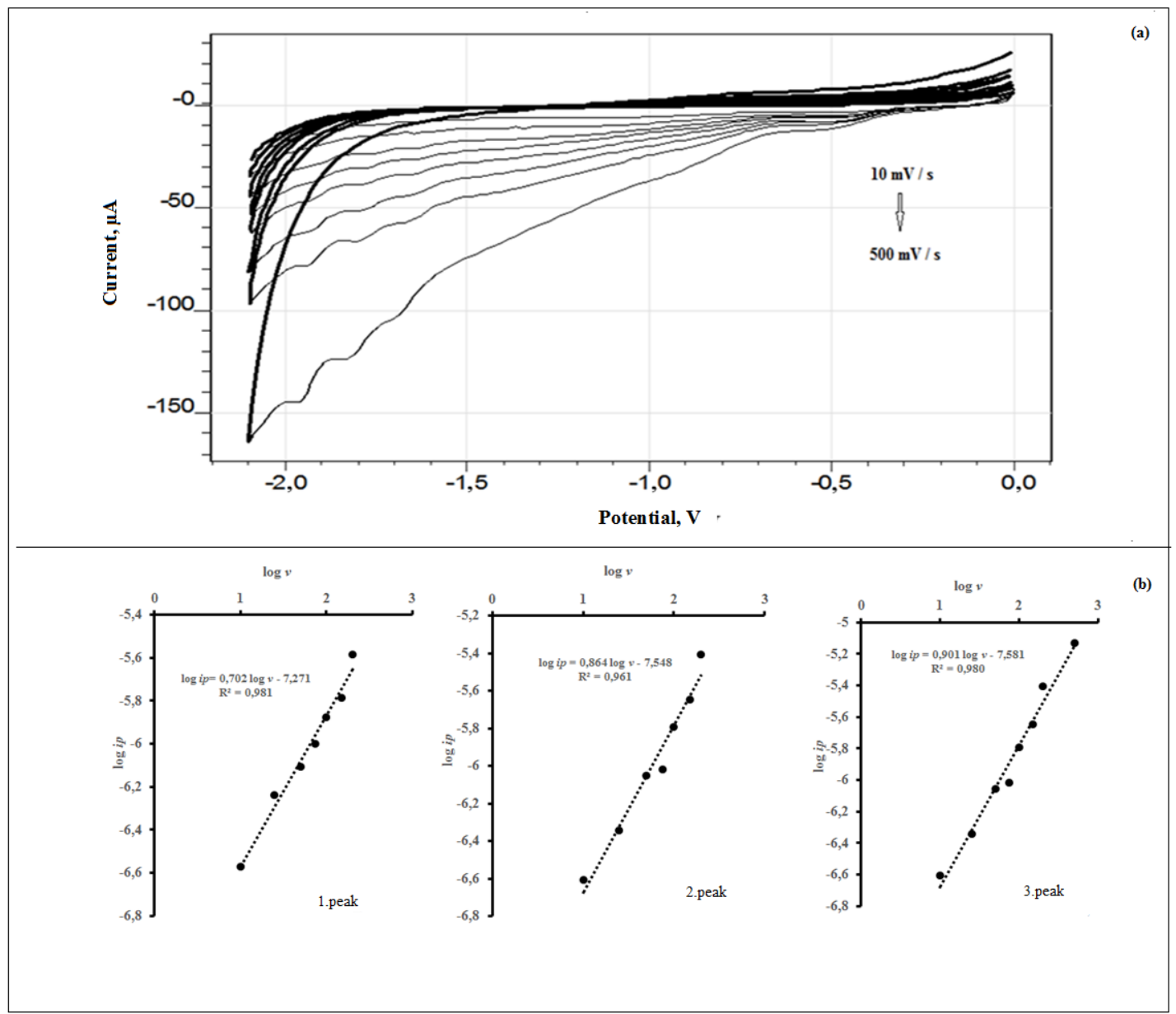

Figure 4.CVs of $4.98 \times 10^{-5} \mathrm{M}$ CPF taken with $\mathrm{RGO} / \mathrm{GCE}$ at different potential scanrates(a) and $\log$ ip-logv $\operatorname{grap}(\mathrm{b})(0.1 \mathrm{M} \mathrm{NaOH}, \mathrm{pH}: 13)$

From the equations, the perfect mixing conditions of diffusion and adsorption controlled processes on the modified electrode surface were observed with the slope values closeto 0.75 for every three peaks(Manisankar et al., 2005). Besides, the adsorption effect of CPF on RGO/GCE was considered that RGO modification resulted in the objectives as well as utilizing in an adsorptive stripping method such as DPAdSV.

\section{Effect of accumulation potential and time on the peak current}

The accumulation step is highly useful to increase the current response of the analyte for 
adsorption-controlled electrochemical reactions. The conditions of the accumulation step were determined by an optimization procedure with three replicate measurements. Figure $5 \mathrm{a}$ and Figure $5 \mathrm{~b}$ show the current responses of $4.98 \times 10^{-5} \mathrm{M}$ of $\mathrm{CPF}$ with accumulation potential $\left(\mathrm{E}_{\text {acc }}\right)$ and period $\left(\mathrm{t}_{\mathrm{acc}}\right)$ carried out between $0 \mathrm{~V}$ and $1.2 \mathrm{~V}$, and from 10 to 140 s by incrementing at $10 \mathrm{~s}$ intervals, respectively. The maximum current response for the electrochemical reduction of CPF was observed at $E_{\text {acc }}$ of $0 \mathrm{~V}$ and $t_{\text {acc }}$ of 30s.In addition, the highest current response was obtained at the third peak of CPF at $-1.80 \mathrm{~V}$ and it was decided to use the third peak of CPF for the electrochemical determination of CPF.

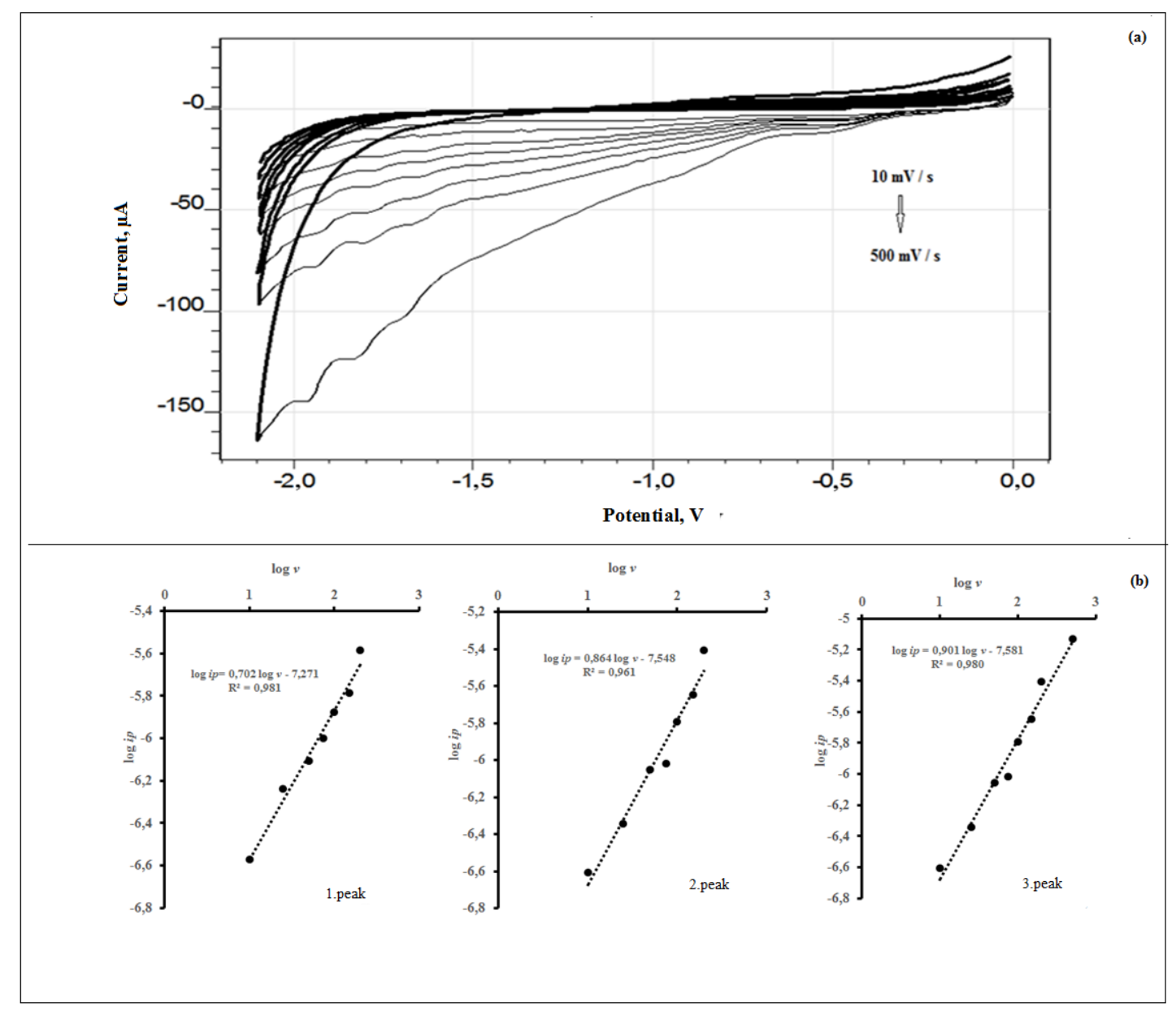

Figure 5.Change of $4.98 \times 10^{-5} \mathrm{M} \mathrm{CPF}$ by the accumulation potential of peak current obtained by DPAdSV

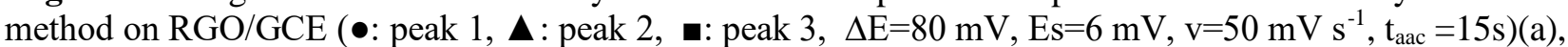
change of $4.98 \times 10^{-5} \mathrm{M} \mathrm{CPF}$ by the accumulation potential of peak current obtained by DPAdSV method on

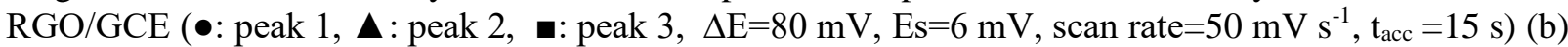

\section{Determination of CPF by DPAdSV}

The quantitative analysis of CPF was carried out by DPAdSV using the calibration curve at RGO/GCE under optimal conditions $(0.1 \mathrm{M} \mathrm{NaOH}$, $\mathrm{E}_{\text {acc: }}: 0 \mathrm{~V}, \mathrm{t}_{\mathrm{acc}}: 30 \mathrm{~s}$ ). The pulse voltammograms at increased concentrations of CPF were shown in Figure 6a., and the corresponding calibration graph was presented in Figure $6 b$. From Figure $6 b$, the sensor developed for the analysis of CPF gave two linear ranges with the following equations:

First: $\mathrm{I}(\mu \mathrm{A})=2167 \quad \mathrm{C}(\mathrm{mM})+1.345 \quad \mathrm{R}^{2}=0.996$ (between $5.19 \times 10^{-7} \mathrm{M}$ and $8.12 \times 10^{-6} \mathrm{M}$ )

Second: $\mathrm{I}(\mu \mathrm{A})=6.448 \mathrm{C}(\mathrm{mM})+19.32 \mathrm{R}^{2}=0.993$ (between $8.12 \times 10^{-6} \mathrm{M}$ and $2.18 \times 10^{-3} \mathrm{M}$ )

The limit of detection(LOD) and limit of quantification(LOQ)were calculated to be $156 \mathrm{~nm}$ 
and $519 \mathrm{~nm}$ using the equation of LOD $=3 \mathrm{~s} / \mathrm{m}$ and $\mathrm{LOQ}=10 \mathrm{~s} / \mathrm{m}$, respectively. The validation results of the RGO modified sensor were presented in Table 1 , it was shown that the obtained LOD value was the lowest for CPF determination with modified solid electrodes from Table 2.

In Table 2, when the LOD values of CPF at GCE and $\mathrm{RGO} / \mathrm{GCE}$ were compared, a lower $(17.46 \%)$ limit of detection was calculated at RGO/GCE. Besides, RGO/GCE is more advantageous than GCE due to its repeated use without cleaning the surface. The enhanced response to CPF arises from the electrocatalytic activity of oxygen-containing functional groups of RGO as a modifier. Although mercury electrodes show lower LODs for the quantitative determination of CPF, the use of mercury may cause environmental problems. In addition, the determination studies performed at RGO/GCE appear to have a lower LOD value compared to those carried out by Sreedar et al., 2015, Kumaravel et al., 2015 and Fischer et al. J., 2016

\section{Repeatability and Selectivity}

Repeatability and reproducibility of the proposed sensor were confirmed by taking DPAdSV measurements of $6.03 \times 10^{-8} \mathrm{M} \mathrm{CPF}$ in $0.1 \mathrm{M} \mathrm{NaOH}$ at various times using modified electrodes. The RSD value of the peak currents showing the repeatability was $0.069 \%$ with the data obtained at different times using the same electrode. The RSD values of repeatability were found to be less than $5 \%$, and the proposed modified electrode was found to show good precision.

To evaluate the selectivity of the proposed sensor, it was utilized against several inorganic compounds probably existing in soil and water. No interference effect was observed for $0.1 \mathrm{mM}$ and $0.5 \mathrm{mM}$ of $\mathrm{Co}^{2+}$, $\mathrm{Ni}^{2+}, \mathrm{Pb}^{2+}$, and $\mathrm{Ca}^{2+}$ nitrates (approximately 1 and 5 folds concentration) with the recovery between $99.9 \%$ and $111.0 \%$, but $\mathrm{Cu}^{2+}$ resulted in an excess deviation with the recovery value of $78.2 \%$ from Table 3.

\section{Assay of CPF intap water}

To confirm the suitability and reliability of the proposed sensor, the standard solution of $\mathrm{CPF}$ and tap water was spiked into $0.1 \mathrm{M} \mathrm{NaOH}$, and then the determination of $\mathrm{CPF}$ in optimized conditions was carried out without following an extraction procedure. Recovery studies of CPF in the tap water were calculated at a $95 \%$ confidence level as listed in Table 4.
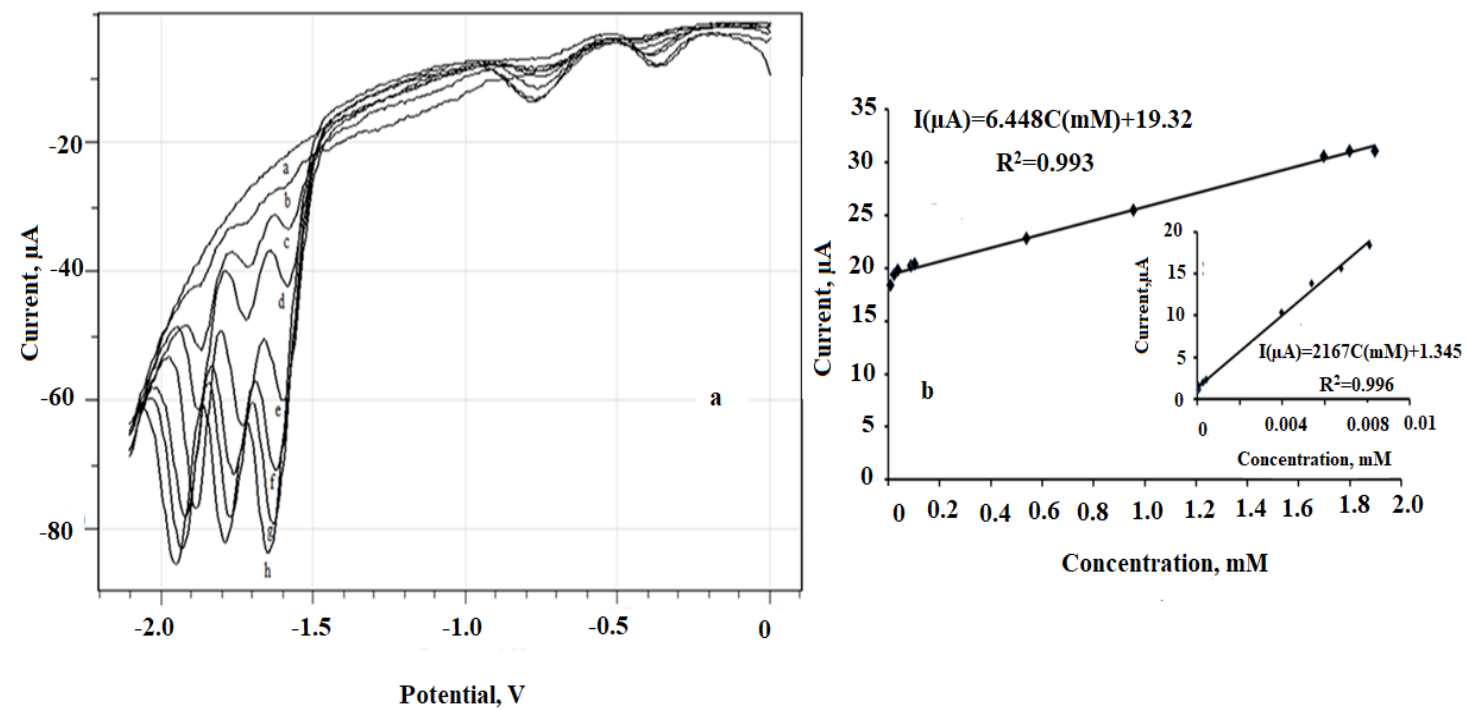

Figure 6.Voltammograms of CPF in different concentrations in $0.1 \mathrm{M} \mathrm{NaOH}$ solution obtained by means of DPAdSV method on RGO/GCE: a) $0.1 \mathrm{M} \mathrm{NaOH}$, b) $6.03 \times 10^{-8} \mathrm{M}$, c) $7.19 \times 10^{-7} \mathrm{M}$, d) $3.91 \times 10^{-6} \mathrm{M}$, e) $3.64 \times 10^{-5} \mathrm{M}$ f) $\left.\left.1.59 \times 10^{-3} \mathrm{M}, \mathrm{g}\right) 1.80 \times 10^{-3} \mathrm{M}, \mathrm{h}\right) 2.08 \times 10^{-3} \mathrm{M} \mathrm{CPF}\left(\Delta \mathrm{E}=80 \mathrm{mV}, \mathrm{Es}=6 \mathrm{mV}, \mathrm{E}_{\mathrm{acc}}=0 \mathrm{~V}, \mathrm{t}_{\mathrm{acc}}=30 \mathrm{~s}\right.$ $\left.\mathrm{v}=50 \mathrm{mV} \mathrm{s}^{-1}\right)(\mathrm{a})$, peak current change with concentration of CPF in $0.1 \mathrm{M} \mathrm{NaOH}$ solution by DPAdSV method on $\mathrm{RGO} / \mathrm{GCE}\left(\Delta \mathrm{E}=80 \mathrm{mV}\right.$, Es $\left.=6 \mathrm{mV}, \mathrm{E}_{\mathrm{acc}}=0 \mathrm{~V}, \mathrm{t}_{\mathrm{acc}}=30 \mathrm{~s}, \mathrm{v}=50 \mathrm{mV} \mathrm{s}^{-1}\right)(\mathrm{b})$ 
Table 1.Analytic parameters identified for determination of CPF using DPAdSV method with RGO/GCE in 0.1 M $\mathrm{NaOH}$ solution

\begin{tabular}{l|l|l}
\hline Parameters & 1. Calibration Curve & 2. Calibration Curve \\
\hline Linear working range $(\mathrm{M})$ & $5.19 \times 10^{-7}-8.12 \times 10^{-6}$ & $8.12 \times 10^{-6}-2.18 \times 10^{-3}$ \\
\hline Slope $(\mu \mathrm{A} / \mathrm{mM})$ & 2167.4 & 6.6448 \\
\hline Correlation coefficient & 0.996 & 0.993 \\
\hline LOD $(\mathrm{M})$ & $1.56 \times 10^{-7}$ & \\
\hline LOQ $(\mathrm{M})$ & $5.19 \times 10^{-7}$ & \\
\hline Peak Potential Repeatability & $0.005^{*}$ & \\
$(\%$ BSS $)$ & & \\
\hline Peak Current Repeatability & $0.069^{*}$ & \\
$(\%$ BSS $)$ & & \\
\hline
\end{tabular}

Table 2. $L O D$ values of studies on electrochemical determination of CPF ( $L O D$ values were convertedin to molarity)

\begin{tabular}{|c|c|c|c|}
\hline Electrode & LOD & Method & Literature \\
\hline Dripping mercury electrode (DME) & $8.7 \times 10^{-7} \mathrm{M}$ & Differential pulse polarographic & $\begin{array}{l}\text { (Al-Meqbali } \\
\text { et al., 1998) }\end{array}$ \\
\hline $\begin{array}{l}\text { Poly 3,4-ethylenedioxythiophene modified } \\
\text { glassy carbon electrode (PEDOT/GCE }\end{array}$ & $8.0 \times 10^{-10} \mathrm{M}$ & Square wave stripping voltammetry & $\begin{array}{l}\text { (Manisankar } \\
\text { et al., 2005) }\end{array}$ \\
\hline Hanging mercury drop electrode (HMDE) & $9.9 \times 10^{-9} \mathrm{M}$ & $\begin{array}{l}\text { Differential pulse cathodic adsorptive } \\
\text { stripping voltammetry }\end{array}$ & $\begin{array}{l}\text { (Al-Meqbali } \\
\text { et al., 1998) }\end{array}$ \\
\hline Hanging mercury drop electrode (HMDE) & $3.9 \times 10^{-10} \mathrm{M}$ & DPAdSV & $\begin{array}{l}\text { (Pelit et al., } \\
\text { 2011) }\end{array}$ \\
\hline Clay modified carbon paste electrode & $2.28 \times 10^{-10} \mathrm{M}$ & DPAdSV & $\begin{array}{l}\text { (Sirisha et } \\
\text { al., 2007) }\end{array}$ \\
\hline $\begin{array}{l}\mathrm{Ag} / \mathrm{Cu} \text { alloy nanoparticles and graphene } \\
\text { composite paste electrode }\end{array}$ & $4.4 \times 10^{-6} \mathrm{M}$ & DPAdSV & $\begin{array}{l}\text { Sreedar et } \\
\text { al., 2015) }\end{array}$ \\
\hline $\begin{array}{l}\text { NanoTiO2/cellulose acetate modified glassy } \\
\text { carbon electrode }\end{array}$ & $3.5 \times 10^{-6} \mathrm{M}$ & DPV & $\begin{array}{l}\text { (Kumaravel } \\
\text { et al., 2015) }\end{array}$ \\
\hline $\begin{array}{l}\text { Mercury Meniscus Modified Silver Solid } \\
\text { Amalgam Electrode }\end{array}$ & $2.6 \times 10^{-6} \mathrm{M}$ & DPV & $\begin{array}{l}\text { (Fischer et } \\
\text { al. J.,2016) }\end{array}$ \\
\hline Hanging mercurydrop electrode & $4.4 \times 10^{-10} \mathrm{M}$ & $\begin{array}{l}\text { Square wave adsorptive stripping } \\
\text { voltammetry }\end{array}$ & $\begin{array}{l}\text { (Melo et } \\
\text { al.,2018) }\end{array}$ \\
\hline GCE & $1.89 \times 10^{-7} \mathrm{M}$ & DPV & Presentstudy \\
\hline RGO/GCE & $1.57 \times 10^{-7} \mathrm{M}$ & DPAdSV & Presentstudy \\
\hline
\end{tabular}


Table 3. Interference effect of certain cations on CPF using DPAdSV method with RGO/GCE

\begin{tabular}{|c|c|c|c|c|c|c|}
\hline $\begin{array}{l}\text { Interfering } \\
\text { ions }\end{array}$ & $\begin{array}{c}\text { For 1. peak } \\
\text { recovery at } \\
\text { the } \\
\text { preference of } \\
1.0 \times 10^{-4} \mathrm{M} \\
\text { interferent } \\
(\%)\end{array}$ & $\begin{array}{c}\text { For 2.peak } \\
\text { recovery at } \\
\text { the } \\
\text { preference of } \\
1.0 \times 10^{-4} \mathrm{M} \\
\text { interferent } \\
(\%)\end{array}$ & 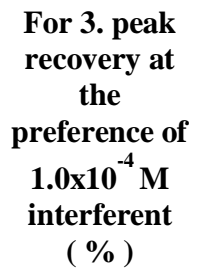 & $\begin{array}{c}\begin{array}{c}\text { For 1.peak } \\
\text { recovery at } \\
\text { the } \\
\text { preference of } \\
5.0 \times 10-4 \\
\text { interferent } \\
(\%)\end{array}\end{array}$ & $\begin{array}{c}\text { For 2.peak } \\
\text { recovery at } \\
\text { the } \\
\text { preference of } \\
5.0 \times 10^{-4} \mathrm{M} \\
\text { interferent } \\
(\%)\end{array}$ & $\begin{array}{c}\text { For 3.peak } \\
\text { recovery at the } \\
\text { preference of } \\
5.0 \times 10^{-4} \mathrm{M} \\
\text { interferent } \\
(\%)\end{array}$ \\
\hline $\mathrm{Cu}^{2+}$ & 106.9 & 101.4 & 78.2 & 46.6 & 35.7 & 17.0 \\
\hline $\mathrm{Ni}^{2+}$ & 96.9 & 101.0 & 99.9 & 92.2 & 80.1 & 84.8 \\
\hline $\mathrm{Co}^{2+}$ & 95.6 & 101.0 & 105.0 & 76.4 & 46.9 & 51.3 \\
\hline $\mathrm{Ca}^{2+}$ & 95.2 & 98.5 & 111.0 & 91.4 & 59.2 & 59.9 \\
\hline $\mathrm{Pb}^{2+}$ & 98.1 & 111.0 & 111.0 & 85.4 & 38.2 & 27.7 \\
\hline
\end{tabular}

Table 4. Recovery values of CPF in tap water using DPAdSV method with RGO/GCE

\begin{tabular}{|c|c|c|c|c|}
\hline $\begin{array}{c}\text { Added } \\
\left(\mu \mathrm{g} \mathrm{mL}^{-1}\right)\end{array}$ & $\begin{array}{c}\text { Found } \\
\left(\mu \mathrm{g} \mathrm{mL}^{-1}\right)\end{array}$ & Recovery (\%) & $\begin{array}{c}\text { Relative standard } \\
\text { deviation }(\%)\end{array}$ & Relative error $(\%)$ \\
\hline 3.51 & $3.5 \pm 0.3$ & 101.0 & 3.26 & 0.99 \\
\hline 7.01 & $7.1 \pm 0.4$ & 101.0 & 2.46 & 0.97 \\
\hline
\end{tabular}

\section{CONCLUSION}

The RGO / GCE, which is novel, sensitive, selective, easily producible and applicable, was proposed as a sensor for determining the CPF.

Two linear working ranges were found in the range of $5.19 \times 10^{-7} \mathrm{M}-8.12 \times 10^{-6} \mathrm{M}$ and $8.12 \times 10^{-6} \mathrm{M}$ $2.18 \times 10^{-3} \mathrm{M}$ in the determination of $\mathrm{CPF}$ by DPAdSV method using the modified electrode. The detection limit was found to be $1.56 \times 10^{-7} \mathrm{M}$. These results indicated that the proposed modified electrode has a wide working range and a low limit of detection for the determination of CPF. The proposed method was applied sensitively and selectively to the determination of CPF in tap water, as a true sample.

\section{ACKNOWLEDGMENT}

The authors gratefully acknowledge the supports of Gazi University under the Scientific Research Fund (05/2017-15) and Munzur University under the

Scientific Research Fund (MFTUB013 02). We also would like to thank Assoc. Prof. Dr.Vahap

YÖNTEN for his help with chemical materials.

\section{CONFLICT OF INTEREST}

The Author report no conflict of interest relevant to this article.

\section{RESEARCH AND PUBLICATION ETHICS STATEMENT}

The author declares that this study complies with research and publication ethics.

\section{REFERENCES}

Al, Meqbali, A. S. R., El Shahawi, M. S.and Kamal, M. M.,1998. Differential pulse polarographic analysis of chlorpyrifos insecticide. Electroanalysis: An International Journal Devoted to Fundamental and Practical Aspects of Electroanalysis, 10(11), 784786.

Çiplak, Z., Yildiz, N. And Çalimli, A., 2015. Investigation of graphene/Ag nanocomposites synthesis parameters for two different synthesis 
methods. Fullerenes, Nanotubes and Carbon Nanostructures, 23(4), 361-370.

Emiru, T. F., and Ayele, D. W., 2017. Controlled synthesis, characterization and reduction of graphene oxide: A convenient method for large scale production. Egyptian Journal of Basic and Applied Sciences, 4(1), 74-79.

Fischer, J., Hájková, A., Pereira, M., Křeček, M., Vyskočil, V., Barek, J. 2016. Investigation of voltammetric behaviour of insecticide chlorpyrifos on a mercury meniscus modified silver solid amalgam electrode. Electrochimica Acta, 216, 510516.

Geim, A. K. And Novoselov, K. S., 2010. The rise of graphene. In Nanoscience and technology: A Collection Of Reviews From Nature Journals ,1119).

Handajani, U. S., Raharjo, Y., And Wantoro, B., 2017. Determination of chlorpyrifos pesticide by effervescence liquid phase microextraction HPLC UV-VIS. Journal Of Chemical Technology And Metallurgy, 52(6), 1056-1061.

Huan, Y., You Ning, M., Mei Ling, Q., Shuang Shuang, C., Qiao, H., Han Tong, Z., And Ren Xiang, M., 2019. Rapid analysis of chlorpyrifos, carbosulfan and their metabolites residues in rice by HPLCMS/MS. Shipin Kexue/Food Science, 40(2), 304309.

Huang, W., Zhou, X., Luan, Y., Cao, Y., Wang, N., Lu, Y. And $\mathrm{Xu}, \mathrm{W} ., 2020$.A sensitive electrochemical sensor modified with multi-walled carbon nanotubes doped molecularly imprinted silica nanospheres for detecting chlorpyrifos. Journal Of Separation Science, 43(5), 954-961.

Johra, F. T., Lee, J. W.and Jung, W. G., 2014. Facile and safe graphene preparation on solution based platform. Journal Of Industrial And Engineering Chemistry, 20(5), 2883-2887.

Joshi, P., Mehtab, S., Zaidi, M. G. H., Tyagi, T., Bisht, A. 2020. Development of polyindole/tungsten carbide nanocomposite-modified electrodes for electrochemical quantification of chlorpyrifos. Journal of Nanostructure in Chemistry, 10(1), 33-45.

Kang, X., Wang, J., Wu, H., Liu, J., Aksay, I. A., Lin, Y., 2010. A graphene-based electrochemical sensor for sensitive detection of paracetamol. Talanta, 81(3), 754-759.

Kang, X., Wang, J., Wu, H., Liu, J., Aksay, I. A., Lin, Y., 2010. A graphene-based electrochemical sensor for sensitive detection of paracetamol. Talanta, 81(3), 754-759.

Koçak, B., Er, E. And Çelikkan, H. , 2015. Stripping voltammetric analysis of dicofol on graphenemodified glassy carbon electrode. Ionics, 21(8), $2337-2344$
Konios, D., Stylianakis, M. M., Stratakis, E.and Kymakis, E., 2014. Dispersion behaviour of graphene oxide and reduced graphene oxide. Journal Of Colloid And Interface Science, 430, 108-112.

Kumaravel, A. And Chandrasekaran, M.,2015. Electrochemical determination of chlorpyrifos on a nano-TiO2/cellulose acetate composite modified glassy carbon electrode. Journal Of Agricultural And Food Chemistry, 63(27), 6150-6156.

Mane, P. C., Shinde, M. D., Varma, S., Chaudhari, B. P., Fatehmulla, A., Shahabuddin, M. And Chaudhari, R., 2020. D.Highly sensitive label-free biointerfacial colorimetric sensor based on silk fibroingold nanocomposite for facile detection of chlorpyrifos pesticide". Scientific Reports, 10(1), 114.

Manisankar, P., Viswanathan, S., Pusphalatha, A. M. And Rani, C., 2005. Electrochemical studies and square wave stripping voltammetry of five common pesticides on poly 3, 4-ethylenedioxythiophene modified wall-jet electrode. Analytica Chimica Acta, 528(2), 157-163.

Manisankar, P.,Sundari, P. A., Sasikumar, R. And Palaniappan, S. P., 2008 Electroanalysis of some common pesticides using conducting polymer/multiwalled carbon nanotubes modified glassy carbon electrode, Talanta, 76(5), 1022-1028.

Melo, L. C., Julião, M. S., Milhome, M. A., do Nascimento, R. F., De Souza, D., de Lima-Neto, P., Correia, A. N. 2018. Square wave adsorptive stripping voltammetry determination of chlorpyriphos in irrigation agricultural water. Journal of Analytical Chemistry, 73(7), 695-704.

Nallapaneni, A.,Pope, C. N., 2005. Chlorpyrifos. Encyclopedia of Toxicology (Second Edition). Elsevier, 583-586.

Novoselov, K. S., Geim, A. K., Morozov, S. V., Jiang, D., Zhang, Y., Dubonos, S. V., and Firsov, A. A., 2004. Electric field effect in atomically thin carbon films. Science, 306(5696), 666-669.

Paredes, J. I.,Villar-Rodil, S., Martinez-Alonso, A. and Toscon, J. M. D.,2008.Graphene oxide dispersions in organic solvents, Langmuir, 24(19), 10560-10564.

Pelit, F. O., Ertaş, H. And Ertaş, F. N., 2011. Development of an adsorptive catalytic stripping voltammetric method for the determination of an endocrine disruptor pesticide chlorpyrifos and its application to the wine samples. Journal of Applied Electrochemistry, 41(11), 1279.

Pope, C.,Karanth, S. And Liu, J., 2005. Pharmacology and toxicology of cholin esterase inhibitors: uses and misuses of a common mechanism of action. Environmental toxicology and pharmacology, 19(3), 433-446.

Sinha, S. N., Pal, R., Dewan, A., Mansuri, M. M. And Saiyed, H. N., 2006. Effect of dissociation energy on 
ion formation and sensitivity of an analytical method for determination of chlorpyrifos in human blood, using gas chromatography-mass spectrometer (GCMS in MS/MS). International Journal of Mass Spectrometry, 253(1-2), 48-57.

Sirisha, K., Mallipattu, S. And Jayarama Reddy, S. R., 2007. Differential pulse adsorptive stripping voltammetric determination of chlorpyrifos at a sepiolite modified carbon paste electrode .Analytical letters, 40(10):1939-1950,

Sirisha, K., Mallipattu, S.and Jayarama Reddy, S. R., 2007. Differential pulse adsorptive stripping voltammetric determination of chlorpyrifos at a sepiolite modified carbon paste electrode. Analytical letters, 40(10), 1939-1950.

Sreedhar, N. Y., Kumar, M. S. And Krishnaveni, K., 2015. Sensitive determination of chlorpyrifos using $\mathrm{Ag} / \mathrm{Cu}$ alloy nanoparticles and graphene composite paste electrode. Sensors and Actuators B: Chemical, 210, 475-482.

Stobinski, L., Lesiak, B., Malolepszy, A., Mazurkiewicz, M., Mierzwa, B., Zemek, J.and Bieloshapka, I., 2014. Graphene oxide and reduced graphene oxide studied by the XRD, TEM and electron spectroscopy methods. Journal of Electron Spectroscopy and Related Phenomena, 195, 145-154.

Wallace, P. R., 1947. The band theory of graphite. Physical review, 71(9), 622.

William, S., Hummers, J. R.and Offeman, R. E., 1958. Preparation of graphitic oxide. J. Am. Chem. Soc, 80(6), 1339-1339.

Yang, W., Ratinac, K. R., Ringer, S. P., Thordarson, P., Gooding, J. J. And Braet, F., 2010. Carbon nanomaterials in biosensors: should you use nanotubes or graphene?. Angewandte Chemie International Edition, 49(12), 2114-2138. 